\title{
Download
}

UDC 911.3:069(477.85) https://doi.org/10.17721/2308-135X.2021.64.42-52

Kostaschuk Ivan Ivanovych, Doctor of Geographical Sciences, Associate Professor Yuriy Fedkovych Chernivtsi National University, Chernivtsi, Ukraine,

e-mail: ivan_kostaschuk@ukr.net

Kisil Roman Volodymyrovych, Yuriy Fedkovych Chernivtsi National University, Chernivtsi, Ukraine,

e-mail: kisil.roman@chnu.edu.ua

\section{TERRITORIAL ORGANIZATION OF MUSEUMS AS OBJECTS OF ETHNOCULTURAL POTENTIAL OF CHERNIVTSI OBLAST}

Goal of the article: Conduct research on the territorial organization of museums of different levels and types in the communities of Chernivtsi oblast as important objects of ethnocultural potential of the region. Identify the distribution of museums by different classification criteria and trace their importance for the development of certain types of tourism.

Research methodology. To obtain information, various sources of information were first studied, namely: literary, official Internet portals of communities and districts of Chernivtsi Oblast State Administration and Chernivtsi Oblast Council. At the next stage, a fairly detailed database was formed, which reflects the types of museums according to all the classification features presented in the work, as well as their ethnicity. This allowed to establish the contribution of 
each ethnic group in the formation of ethnocultural potential of the region, which allows us to talk about cooperation with neighboring countries in the framework of ethnocultural interaction.

Results of the research. Chernivtsi oblast is a striking example of ethnocontact and polyethnic region, in which Ukrainians, Romanians, Moldovans, Jews, Russians, Poles, Armenians and other ethnic groups created and continue to create their cultural heritage. Ukrainians in the region own 152 museums, Romanians - 12, Moldovans - 14, Russians - 1. Also, separate exhibitions are dedicated to the Jewish, Polish, German, Armenian and other ethnic groups. Of course, such differences in the ethnicity of museums, as an important component of ethnocultural development of the region, are of great practical and scientific importance.

The scientific novelty lies in the development of a detailed classification of museums and their typology, as well as in identifying the place of museums in the ethnocultural development of the polyethnic region. These studies should be conducted in other regions of our country.

The practical significance of the obtained results lies in the possibility of finding investments to increase the tourist attractiveness of both individual administrative units and the region as a whole. Museums also play an important role in shaping the ethnic, historical, ethnocultural, national-patriotic and other perceptions of the territory and identity of their people.

Key words: museums, classification of museums, ethnocultural potential of museums.

\section{References}

1. Antoniuk-Havryshchuk Ye. Muzei Bukovyny : monohrafiia. Chernivtsi : Vydavnychyi dim «Bukrek», 2007. 192 s.

2. Zatulovska O.P., Piddubnyi I.A., Skilskyi I.V. Peredmova. Suchasnyi muzei: naukova y ekspozytsiina diialnist : materialy naukovoi konferentsii, prysviachenoi 145 -i richnytsi zasnuvannia Kraiovoho muzeiu v Chernivtsiakh, 15 hrudnia 2008 r. Chernivtsi, 2008. S. 3-5. 
3. Havryshchuk Ye. Diialnist memorialnykh muzeiv Bukovyny. Bukovynskyi zhurnal. 2006. №1. S. 214-220.

4. Liubkivska V., Kitsul I. 20 rokiv z zhyttia Chernivetskoho khudozhnoho muzeiu: zdobutky i problemy. Khudozhnii muzei pochatku $21 \mathrm{st}$. i yoho rol u formuvanni suchasnoho kulturnoho seredovyshcha : materialy mizhnarodnoi naukovo-praktychnoi konferentsii do 20-richchia Chernivetskoho oblasnoho khudozhnoho muzeiu. Chernivtsi : Zoloti lytavry, 2008. $84 \mathrm{~s}$.

5. Rutynskyi M.Y. Muzeieznavstvo : navch. posib. Kyiv : Znannia, 2008. 428 c.

6. Sanduliak I. Muzeini ustanovy pivnichnoi chastyny Bukovyny yak turystychni ob'iekty $50-80$ rr. KhKh st. Pytannia starodavnoi ta serednovichnoi istorii, arkheolohii y etnolohii. 2006. T. 2 (22). S. 228-237. 